\title{
Peranan Sektor Agroindustri Dalam Pembangunan Nasional
}

Oleh: Iis Turniasih ${ }^{*}$, Nia Kania Dewi ${ }^{* *}$

\begin{abstract}
Abstrak
Kultur masyarakat Indonesia adalah petani. Akan tetapi, pertumbuhan dan perkembangannya hingga saat ini belum mampu menjadi sektor andalan dalam perekonomian negara. Banyak faktor yang mempengaruhi pertumbuhan dan perkembangannya tersebut. Salah satu alternatif pemecahan masalah tersebut adalah dengan mengembangkan sektor pertanian melalui agroindustri. Manajemen industri dalam sektor pertanian sangat diharapkan sebagai upaya percepatan sehingga sektor ini dapat menjadi andalan pendapatan negara, dan yang terpenting adalah mampu meningkatkan kesejahteraan petani.
\end{abstract}

Kata kunci: agroindusutri, pertanian.

*) Iis Turniasih, S.Pd adalah guru Geografi SMA Negeri 22 Bandung.

**) Nia Kania Dewi, S.Pd adalah guru IPS SMP Negeri 36 Bandung 


\section{Pendahuluan}

Indonesia adalah negara kepulauan yang mempunyai wilayah daratan yang luas, sehingga sebagian besar penduduknya bermata pencaharian sebagai petani. Potensi ini perlu dikembangkan dengan menjadikan hasil pertanian dijadikan komoditi ekspor dan sumber bagi pembangunan bangsa Indonesia.

Sesuai dengan modal dasar yang dimiliki oleh bangsa Indonesia, alternatif yang sangat potensial untuk dikembangkan dalam menghadapi arus globalisasi dan regeonalisasi ekonomi tersebut adalah sektor industri yang mempunyai kaitan langsung dengan sektor pertanian (agroindustri).

Sektor agroindustri sekarang ini sedang mendapat perhatian besar dari khalayak dan pemerintah untuk dapat di kembangkan sebagai modal pembangunan yang diharapkan dapat memberikan sumbangan bagi pelaksanaan pembangunan.

Dalam pembahasan modal pembangunan nasional ini membatasi tentang peranan sektor agroindustri dalam pembangunan nasional terutama pembangunan dalam sektor pertanian agar masyarakat lebih mengenal dan mampu mengembangkan sektor agroindustri tersebut.

\section{Pengertian Agroindustri}

Agroindustri adalah pengolahan hasil pertanian dengan mengoptimalkan lahan pertanian sebagai sumber agrobisnis. Menurut Soekartawi (1991) ada enam subsistem dari agrobisnis, yaitu :

a) Penyediaan sarana produksi dan peralatan

b) Usaha tani

c) Pengolahan hasil (agroindustri)

d) Pemasaran

e) Sarana

f) Pembinaan

Keenam subsistem agrobisnis ini perlu dikembangkan karena sangat menunjang dalam melaksanaan pembangunan. Agroindustri merupakan fase pertumbuhan setelah pembangunan pertanian, tetapi 
sebelum pembangunan tersebut memulai ke tahapan pembangunan industri. Agroindustri dapat dibedakan menjadi :

a) Agroindustri adalah industri yang berbahan baku utama dari produk pertanian.

b) Agroindustri adalah suatu tahapan pembangunan sebagai kelanjutan dari pembangunan pertanian, tetapi sebelum mencapai tahapan pembangunan industri.

\section{Visi Pembangunan Agroindustri}

Visi dari pembangunan agroindustri, khususnya di negara yang sedang berkembang sepertihalnya negara Indonesia adalah sebagai berikut :

a) Agroindustri yang tumbuh dan berkembang secara berkelanjutan

b) Mampu berkompetisi

c) Mampu merespon dinamikan perubahan pasar dan pesaing, baik dipasaran domistik maupun pasaran internasional

d) Mampu meningkatkan kontribusinya terhadap perekonomian nasional

e) Mampu ikut meningkatkan kesejahteraan masyarakat

Oleh karena itu untuk mencapai visi tersebut maka dapat dilakukan dengan cara berikut:

a) Melakukan penyesuaian terhadap perubahan global

b) Meningkatkan pertumbuhan melalui inovasi, investasi dan perdagangan

c) Menghilangkan faktor-faktor yang menghambat pertumbuhan

d) Meningkatkan efisiensi di semua sektor

e) Meningkatkan kualitas manajerial

f) Meningkatkan kemandirian agar tidak tergantung pada fasilitas pemerintah

Untuk dapat mencapai visi tersebut dengan melakukan tindakantindakan yang berhubungan dengan pencapaian visi ini, maka disarankan 
agar menerapkan prinsip-prinsip pembangunan yang berkelanjutan, agar pembangunan dapat berjalan sesuai dengan yang diharapkan.

\section{Peranan Agroindustri}

Agroindustri sebagai salah satu sektor yang mampu meningkatkan pendapatan para pelaku agrobisnis, mampu meningkatkan perolehan devisa dan mampu mendorong munculnya industri baru yang lain. Sehingga agroindustri merupakan salah satu hal yang mampu meningkatkan pembangunan nasional.

Pengembangan agroindustri merupakan suatu upaya yang sangat penting untuk mencapai beberapa tujuan yang dianggap dapat membantu pembangunan sektor ekonomi dan kesejahteraan dari masyarakat seperti :

a) Menarik dan mendorong munculnya industri baru di sektor pertanian

b) Meningkatkan penerimaan devisa

c) Menciptakan lapangan kerja

d) Memperbaiki pembagian pendapatan

e) Menciptakan sektor pertanian yang tangguh dan unggul

Sebagai motor penggerak pembangunan pertanian, agrobisnis dan agroindustri akan memainkan peranan penting dalam kegiatan pembangunan, baik dalam sasaran pemerataan pembangunan, pertimbuhan ekonomi dan stabilitas nasional. Dengan melihat dan tanggap terhadap potensi yang ada, diharapkan pelaku bisnis dapat melihat peluang yang tinggi dan kesempatan yang besar untuk meningkatkan dan melaksanakan pembangunan dalam pertanian di Indonesia yang menjadi komoditas eksport.

Mengingat jenis industri pertanian yang dapat dikembangkan di pedesaan memiliki peluang yang besar, maka perlu diprioritaskan pertumbuhan agroindustri yang mampu menangkap efek ganda yang tinggi, baik bagi pembangunan nasional maupun pembangunan ekonomi daerah pada umumnya, khususnya pembangunan perekonomian masayarakat pedesaan. Berbagai peluang yang ada untuk menumbuhkan 
wawasan agrobisnis dan agroindustri di pedesaan ini antara lain mencakup berbagai aspek, seperti: lingkungan strategis, permintaan, sumber daya, dan teknologi. Untuk itu semua tentunya tidak terlepas betapa besarnya peranan swasta, khususnya perbankkan sebagai sumber permodalan dalam pembangunan agroindustri.

Bangsa Indonesia masih akin tetap bergantung pada agroindustri, miscount bukan menjadikannya sebagai sumber devisa utama. Bidang ini harus mendapat perhatian bersama, karena meupakan hal sangat utama. Agroindustri dapat kita kembangkan dengan menggunakan teknologi canggih yang sejajar dengan pengembangan sumber daya manusianya. Negara Indonesia harus mampu meningkatkan agraindustri tersebut karena secara alamiah sangat potensial dengan keadaan alam yang dimilikinya. Karena itu, perlu meningkatkan efesiensi dan produktivitas pertanian dengan memanfaatkan ilmu dan teknologi seoptimal mungkin untuk dapat menunjang pelaksanaan pembangunan tersebut.

\section{Konsep dan Cakupan Agroindustri Serta Prospeknya}

Agroindustri adalah kegiatan lintas disiplin yang memanfaatkan pertanian sebagai sumber daya alam untuk kegiatan industri yang mencakup :

a) Industri peralatan dan mesin pertanian

b) Industri pengolahan hasil pertanian

c) Industri jasa sektor pertanian

Prospek agroindustri dan bisnis ini diperkirakan akin mendominasi perkembangan sektor industri di Indonesia, termasuk hasil eksport industrinya. Apaun yang menjadi pilihan industri di masa depan sebagai andalan, adanya kebijakan yang mencakup "broad spectrum" ragam industri yang memiliki potensi eksport non migas, ataupun penentu industri andalan dengan produk andalan. Jalur agroindustri tidak banyak menghadapi saingan untuk tropicalculture. Karena semua level teknologi dapat diterapkan dalam pengolahan hasil pertanian, bahkan nuklir pun 
dapat dipakai dalam pengawetan bahan makanan, begitupun dengan biotek dapat mencakup didalamnya.

Dalam hal ini ada beberapa faktor pendukung yang perlu diperhatikan, seperti: bahan baku, teknologi, sarana, peralatan, dana, investasi, pasar, dan sumber daya manusia. Bahkan dalam GBHN telah mengamanatkan tentang perlunya pengembangan industri pengolahan (agroindustri) menajadikan salah satu prioritas dalam Pembangunan Nasional di dalam sektor pertanian.

Permasalahan dalam pengembangan agroibisnis dan agroindustri adalah lemahnya keterkaitan antara subsistem di dalam agrobisnis, yaitu distribusi dan penyediaan faktor produksi, proses produksi pertanian, pengolahan dan pemasaran. Dukungan dalam bentuk sarana dan prasarana fisik serta ekonomi perlu ditingkatkan dan diperluas, sedang keterpaduan perencanaan dan pelaksanaannya harus terus ditingkatkan.

Kualitas sumber daya manusia khususnya dipedesaan yang jumlahnya terbatas memerlukan adanya pelatihan profesionalisme usaha dan pendidikan manajemen serta peranan lembaga finansial yang mendukung pengembangan agrobisnis perlu segera ditingkatkan,

Pengembangan ilmu pengetahuan dan teknologi tidak diragukan lagi, sangat diperlukan dalam pengembangan agrobisnis yang terpadu dan berkelanjutan. Dalam hal ini maka ilmu pengetahuan dan teknologi perlu diarahkan pada penemuan dan rekayasa teknologi yang bisa diterpkan dalam pengembangan agrobisnis dan agroindustri.

Beberapa permasalahan agroindustri tersebut, khususnya adalah permasalahan yang ada di dalam negeri, seperti :

a) Kurang tersedianya bahan baku yang cukup dan continue

b) Kurang nyatanya peranan agroindustri di pedesaan karena masih berkonsentrasi pada agroindustri di perkotaan

c) Kurangnya konsisten kebijakan pemerintah terhadap agroindustri

d) Kurangnya fasilitas permodalan (kredit), walaupun ada, prosedur yang digunakan terlalu berbelit dan sangat mempersulit peminjam

e) Keterbatasan pasar 
f) Lemahnya infrastruktur

g) Kurangnya perhatian terhadap penelitian dan pengembangan

h) Lemahnya keterkaitan industri hulu dan hilir

i) Kualitas produksi dan prosessing yang belum mampu bersaing

j) Lemahnya enterpreneurship

\section{Prioritas Solusi}

Adapun yang menjadi prioritas solusi untuk mengatasi permasalahan tersebut diatas, diantaranya adalah :

a) Identifikasi kebutuhan tenaga, yang meliputi bidang keahlian, skala usaha, dan jenis kelembagaan usaha yang mengacu pada tahapan perencanaan, baik untuk jangka pendek, jangka menengah, maupun jangka pangjang

b) Diperlukan koordinasi antara pemakai (swasta, koperasi, dan pemerintah) dengan lembanga pendidikan dan elatihan dalam rangka ketenagaan agroindustri

c) Reorientasi wawasan dan arah pengembangan ketanagaan, mengacu kepada penciptaan lapangan kerja. Untuk itu kurikulum dalam pendidikan dan pelatihan harus menampung kebutuhan terjadinya tranformasi sektor usaha dari tradisional yang berorientasi produk bahan mentah ke sektor modern dengan pemberian nilai tambah sekaligus memperluas kesempatan kerja yang didukung oleh tenaga kerja yang terampil, baik teknis, manajerial, maupun sosialnya.

\section{Penutup}

Indonesia sebagai negara agraris sangat potensial untuk mengembangan pembangunan disektor pertanian yang dapat menunjang sektor ekonomi dan sosial yang dapat menciptakan lapangan kerja baru. Salah satu yang dijadikan sebagai sasaran dalam GBHN adalah dengan mengembangkan agrobisnis dan agroindustri sebagai penghasil devisa 
negara yang mempunyai kemampuan untuk meningkatkan komoditi eksport dan dapat bersaing dalam pasar internasional.

Untuk dapat menciptakan tujuan tersebut diatas, maka perlu kiranya adanya dukungan dari semua pihak, baik itu swasta, koperasi, maupun pemerintahan dan lembaga atau instansi terkait yang dianggap mampu meningkatkan peran dan fungsinya dalam meningkatkan pembangunan dibidang pertanian tersebut.

Permasalahan yang dihadapi harus dapat diatasi dan diberikan solusinya, sehingga apa yang menjadi target dalam mencapaian tujuan nasional bangsa Indonesia dapat terwujud, yang diantaranya adalah dengan berupaya untuk meningkatkan kesejahteraan masyarakat.

Upaya tersebut memang tidak mudah, oleh karenanya diperlukan pelaksanaan dengan penuh rencana, terprogram, berkelanjutan, merata, keseriusan dan terus menerus. Dukungan sumber daya alam yang sangat potensial perlu diikuti dengan peningkatan sumber daya manusianya, karena manusia adalah pelaksana dalam pembangunan. Sehingga dibutuhkan sumber daya manusia yang potensia, kreatif, dan inovatif untuk terlibata dalam pelaksanaan pembangunan nasional.

Apabila hal-hal tersebut sudah dijalankan dengan baik, maka apa yang menjadi visi dari pembangunan agroindustri yang sangat mendukung pada pembangunan ekonomi dan sosial akan dapat terwujud dengan baik.

\section{Daftar Pustaka}

Biro Pusat Statistik, 2000, Sensus Pertanian.

Tani Lestari, 1998, Aneka Ragam Hayati: Kekayaan dan Kekuatan Petani, dalam Media Komunikasi-Informasi dan Motivasi Petani dan Nelayan Lestari. No. 3 Th. VI Oktober.

Pusat Penelitian Pembangunan Pedesaan dan Kawasan UGM, 1998, Kajian Pembangunan Pertanian Abad ke-21 Sistem Pertanian Berkebudayaan industri dan Strategi Operasional Repelita VII, Yogyakarta. 